\title{
シリコン酸窒化膜の安定性と電子構造に関する理論研究の現状
}

\author{
土井謙太郎 $* 1 \cdot$ 吉田 聖一 $* 1 \cdot$ 上原 寛貴 $* 1 \cdot$ 阪本 俊夫 $* 1 \cdot$ 立花 明知*1
}

\section{Present Progress on Theoretical Studies of Stability and Electronic Structures of Silicon Oxynitride Thin Film}

\author{
Kentaro DOI, Seiichi YOSHIDA, Hiroki UEHARA, Toshio SAKAMOTO and Akitomo TACHIBANA \\ Department of Micro Engineering, Kyoto University, Kyoto 606-8501, Japan
}

(Received June 4, 2007, Accepted September 1, 2007)

\begin{abstract}
Recent progress of complementary metal-oxide-semiconductor (CMOS) technology is remarkable and a lot of hot issues for science and technology have been published. Scaling down of the electronic devices is essential for their development but decreases their reliability. In such a small device, a dielectric thin film such as silicon dioxide is required to be the thickness of about $1 \mathrm{~nm}$, and dielectric breakdown caused by leakage current is one of the serious problems. On the other hand, several methods are known to improve quality of the gate insulators. For example, nitridation of silicon dioxide is effective to suppress the leakage current and boron penetration, and employing high- $k$ dielectrics is another way to decrease equivalent oxide thickness (EOT). In this article, nitridation process and dielectric properties of oxynitride thin film are especially focused on and reviewed by treating some important theoretical and experimental reports.
\end{abstract}

\section{1. はじめに}

近年，相補性金属酸化物半導体（CMOS）の更なる高集 積化と微細化のために, 電界効果トランジスタ（MOSFET） のゲート絶緑膜に対する要求が限界に達しているといっても 過言ではなく, シリコンテクノロジーによる次世代半導体を 現実のものにするためのブレークスルーが切望されている. なかでも，シリコン基板上の絶縁膜に対しては高誘電率と信 頼性といった相反する両面が要求される. シリコン酸化膜に おいては, $1 \mathrm{~nm}$ 前後の膜厚が要求されるが，そこでは電極 からのボロン拡散や電気的ストレスに起因するリーク電流の 増加のため, 絶縁膜の寿命は信頼性を満足するには及ばな い. そこで, 上記の問題を回避する方法として, $\mathrm{Si} / \mathrm{SiO}_{2}$ 界 面を窒化することにより, ボロンの拡散およびリーク電流を 抑制する方法 $\left.{ }^{1-9}\right)$ と, $\mathrm{SiO}_{2}$ 膜に変わる高誘電率ゲート絶縁膜 の探索という方法10-17) が考えられている. 現在, 両分野々 もに盛んに研究が行われており, 興味深い結果が多く発表さ れているとともに，更なる問題点も明らかにされてい $ろ^{7,18-20)}$.

一方, 数ナノメートルの絶縁膜は数原子層の膜厚に換算さ れることから, 膜構造および電子構造については, 第一原理 計算に基づいた計算が行われることが一般的になりつつあ る. 実験より求まるバンドオフセットを用いたWKB 近似 によるリーク電流の計算 ${ }^{21,22)}$ から第一原理計算による構造安 定性の計算 ${ }^{23,24)}$, バンド構造解析 ${ }^{25,26)}$, さらには誘電率の計

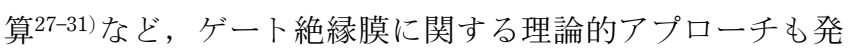
展を続けている. 本稿では, シリコン酸窒化膜の形成過程と その誘電物性に注目し, 実験事実に基づきながら理論的側面 を紹介する。

\footnotetext{
*1 京都大学大学院工学研究科マイクロエンジニアリング専攻 （干606-8501 京都市左京区吉田本町）
}

\section{2. 酸窒化膜の形成過程}

\section{1 熱窒化とプラズマ窒化による膜形成過程}

シリコン基板上に酸窒化膜を形成する方法として, 熱酸窒 化, 化学蒸着 (CVD), プラズマ窒化による方法などが知ら れている6,8,32). しかし，製膜方法と使用するガスによって 形成される酸窒化膜や $\mathrm{Si} / \mathrm{SiON}$ 界面状態に違いが見られる ことが報告されている6,32). Ang らの報告 ${ }^{32}$ によると, 熱酸 窒化により $\mathrm{SiON}$ 膜を生成する場合は, $\mathrm{Si} / \mathrm{SiON}$ 界面に $\mathrm{N}$ 原子が集中するが, $\mathrm{SiO}_{2}$ 膜をプラズマ窒化する場合は電極 側に $\mathrm{N}$ 原子が集中することになり，薄膜の特性に違いがみ られる。pMOSFET に対して, 窒素含有量 $3 \%$, 膜厚 2.6 $\mathrm{nm}$ の酸窒化膜を形成し, $-3 \mathrm{~V}$ の負バイアスかつ $125^{\circ} \mathrm{C}$ の トレス状況下で熱酸窒化した膜とプラズマ窒化したものを比 較した場合, 閾值電圧のシフト $\left(\Delta V_{\mathrm{th}}\right)$ と界面トラップ密 度 $\left(D_{\mathrm{it}}\right)$ ともに熱酸窒化した膜のほうが大きいという結果 が得られている.この結果から, 界面における $\mathrm{N}$ 原子の集 中は界面に欠陥を生成し, FET の挙動を劣化させると考え られる．このことは，負バイアス温度不安定性（NBTI）と して古くから知られている7,18-20,33). NBTIの機構について は, 理論的考察を含めて後述する. 熱酸窒化により絶縁膜を 製膜する場合, $\mathrm{NO}$ または $\mathrm{N}_{2} \mathrm{O}$ ガスを用いることが一般的 である。ただし， $\mathrm{N}_{2} \mathrm{O}$ ガスは活性であるため，高温におけ る窒化では $\mathrm{NO}, \mathrm{N}_{2}, \mathrm{O}_{2}, \mathrm{O}$ による反応が支配的であるとされ る ${ }^{4-6)}$. 一方, $\mathrm{NH}_{3}$ による窒化は, $\mathrm{N}$ 原子の均一分布による 良好な酸窒化膜を得ることができる反面, 膜内に多量の $\mathrm{H}$ 原子を注入することになり，これが膜中のトラップにつなが ると考えられている6,9).

\section{2 窒化膜の安定性と不安定性}

$\mathrm{SiO}_{2}$ 膜を窒化する主な目的は, 薄膜内における不純物原 子の運動を抑制することと電気的ストレス下でのリーク電流 の抑制である. 加えて, 酸窒化膜を形成することにより界面 に存在する $\mathrm{N}$ 原子は $\mathrm{Si}-\mathrm{N}$ 結合および $\mathrm{O}-\mathrm{N}$ 結合を形成する 
ために2,4,6), 界面に抢けるホットキャリアに対する抵抗の増 加, チャージトラップの減少, 誘電率の向上, 破壊に至るま での蓄電荷 $\left(Q_{\mathrm{bd}}\right)$ の増加がみられる1,4,5,9,32).

その一方で, $\mathrm{Si} / \mathrm{SiO}_{2}$ 界面に多量の $\mathrm{N}$ 原子が集中すること により，ホールトラップ中心の増加とともに水素原子トラッ プ中心の増加をもたらすことが示唆されている. KushidaAbdelghafar ら7)は, $\mathrm{NO}$ ガスにより窒化した $\mathrm{SiO}_{2}$ ゲート絶 縁膜に対して, NBTストレス $\left(-6.3 \mathrm{MV} / \mathrm{cm}, 125^{\circ} \mathrm{C}\right)$ と Fowler-Nordheim (FN) ストレス $(-10 \mathrm{MV} / \mathrm{cm}$, 室温) を印加した場合の膜の劣化を膜中の窒素含有量に対して調べ ている. FN ストレスに対しては, 膜中の窒素含有量の増加 に伴って $D_{\mathrm{it}}$ の減少がみられるが，NBTストレスに対して は, 窒素含有量が $0.3-3 \%$ 範囲で $D_{\mathrm{it}}$ が最小となるという 結果を得ている。 また， $\mathrm{NO}$ ガスによる窒化の際の $\mathrm{H}_{2}$ ガス の有無について $D_{\mathrm{it}}$ の時間变化を見た結果, NBTストレス に対しては $\mathrm{H}_{2}$ ガスを含む場合に $D_{\mathrm{it}}$ の増加が見られ, 膜中 の水素が NBTI を引き起こす原因であることが明らかにさ れた．一方， FN ストレスについては， $\mathrm{H}_{2}$ ガスを含まず $\mathrm{NO}$ ガスのみで窒化した場合においても $D_{\mathrm{it}}$ の緩やかな増加がみ られる. 以上の結果から, NBT ストレスによって界面に存 在する $\mathrm{Si}-\mathrm{H}$ 結合は切断されるが， $\mathrm{Si}-\mathrm{N}$ 結合を切断するだ けのエネルギー供給はないといえる，一方，FN ストレス印 加の場合は, $\mathrm{Si}-\mathrm{H}$ 結合の解離に続いて $\mathrm{Si}-\mathrm{N}$ 結合までも解 離するだけのエネルギー供給が考えられる。さらに， Kushida-Abdelghafar $ら^{7)}$ は上記の結果と考察を確かめるた めに，界面モデルに対して第一原理計算を用いることにより， $\mathrm{Si} / \mathrm{SiO}_{2}$ 界面に打けるホール注入と $\mathrm{H}$ 原子の移動について計 算を行っている. その結果, $\mathrm{Si} / \mathrm{SiO}_{2}$ 界面に比べて $\mathrm{Si} / \mathrm{SiON}$ 界面に対するホール注入は容易であり, さらにその後に $\mathrm{Si}-$ $\mathrm{H}$ 結合から解離した $\mathrm{H}$ 原子が $\mathrm{N}$ 原子上のホールと反応する ことは, $\mathrm{O}$ 原子上のホールと反応するよりも容易であるとい う結果を得ている. 反応式を以下に示す.

$$
\begin{aligned}
& \left(\mathrm{Si}_{3} \equiv \mathrm{Si}\right)_{2} \mathrm{NSi} \equiv \mathrm{O}_{3}+h^{+} \\
& \quad \longrightarrow\left(\mathrm{Si}_{3} \equiv \mathrm{Si}\right)_{2} \mathrm{~N}^{+} \mathrm{Si} \equiv \mathrm{O}_{3} \\
& \left(\mathrm{Si}_{3} \equiv \mathrm{Si}\right)_{2} \mathrm{~N}^{+} \mathrm{Si} \equiv \mathrm{O}_{3}+\mathrm{Si}_{3} \equiv \mathrm{SiH} \\
& \stackrel{(\mathrm{Si}}{\longrightarrow} \equiv \mathrm{Si})_{2} \mathrm{~N}^{+} \mathrm{HSi} \equiv \mathrm{O}_{3}+\mathrm{Si}_{3} \equiv \mathrm{Si} \bullet
\end{aligned}
$$

この結果から, 過剰の窒化はホールトラップの原因となり, さらには $\mathrm{Si}-\mathrm{H}$ 結合の解離による $\mathrm{Si}$ 原子上のダングリング ボンドを生成することになる.

\subsection{NBTI によるトラップ生成機構}

NBTI による界面および酸化膜の劣化については古くから 知られている7,18-20,33). NBTI は界面の欠陷準位と酸化膜中 の固定電荷 $\left(Q_{\mathrm{f}}\right)$ の増加に起因するとされているが, 界面 準位と固定電荷の生成メカニズムには, 膜中の水素種の挙動 が原因であるとするモデルとそれ以外の化学反応に原因があ るとするモデルが知られている18,19).

\subsection{1 水素種の挙動に起因する NBTI}

シリコン基板表面に存在する $\mathrm{Si}$ のダングリングボンド $\left(\mathrm{Si}_{3} \equiv \mathrm{Si} \bullet\right)$ を終端している $\mathrm{H}$ 原子は， $\mathrm{Si}$ 原子から解離して 膜中に放出されることが考えられる ${ }^{19)}$. $\mathrm{Si}-\mathrm{H}$ 結合の解離に は外部電場の影響による場合と

$$
\mathrm{Si}_{3} \equiv \mathrm{SiH} \longrightarrow \mathrm{Si}_{3} \equiv \mathrm{Si} \bullet+\mathrm{H}
$$

ホットホールの注入による場合が考えられる.

$$
\mathrm{Si}_{3} \equiv \mathrm{SiH}+h^{+} \longrightarrow \mathrm{Si}_{3} \equiv \mathrm{Si} \bullet+\mathrm{H}^{+}
$$

界面近傍の $\mathrm{H}^{+}$は, さらに $\mathrm{Si}$ を終端している $\mathrm{H}$ 原子と反応 するとされる.

$$
\mathrm{Si}_{3} \equiv \mathrm{SiH}+\mathrm{H}^{+} \longrightarrow \mathrm{Si}_{3} \equiv \mathrm{Si} \bullet+\mathrm{H}_{2}
$$

上記のように, $\mathrm{Si} / \mathrm{SiO}_{2}$ 界面には $\mathrm{Si・による} D_{\mathrm{it}}$ が生成し, 膜 中に放出された $\mathrm{H}^{+}$は逆バイアスの電場に加速されて, $\mathrm{Si} /$ $\mathrm{SiO}_{2}$ 界面から電極側へ移動することにより FET の劣化が促 進されると考えられている.

$\mathrm{Si} / \mathrm{SiO}_{2}$ 界面と同様にして $\mathrm{SiO}_{2}$ 膜中での $\mathrm{H}$ または $\mathrm{H}^{+}$の 放出の結果, $\mathrm{Si}$ 原子上に $Q_{\mathrm{f}}$ が生成される ${ }^{19)} . \mathrm{SiO}_{2}$ 膜中に注 入されたホットホールにより以下の反応が起こるとされる.

$$
\mathrm{O}_{3} \equiv \mathrm{SiH}+h^{+} \longrightarrow \mathrm{O}_{3} \equiv \mathrm{Si}^{+}+\mathrm{H}
$$

また，水分子などの化学種 $(A)$ を介することにより

$$
\mathrm{O}_{3} \equiv \mathrm{SiH}+A+h^{+} \longrightarrow \mathrm{O}_{3} \equiv \mathrm{Si} \bullet+\mathrm{H}^{+}
$$

といった反応が考えられ，このようにして膜中に存在する $Q_{\mathrm{f}}$ や水素種が原因となり $\Delta V_{\mathrm{th}}$ が起こるとされる.

\subsection{2 その他の化学反応による NBTI}

$\mathrm{NBT}$ ストレスによる $D_{\mathrm{it}}$ や膜中の $Q_{\mathrm{f}}$ の生成による NBTI の原因は水素種の挙動だけではなく，その他の化学種を介す ることについてもモデルが考えられている19). 例えば,

$$
\mathrm{Si}_{3} \equiv \mathrm{SiH}+Y \longrightarrow \mathrm{Si}_{3} \equiv \mathrm{Si} \bullet+X
$$

といった反応の場合, $\mathrm{Si} / \mathrm{SiO}_{2}$ 界面近傍の $Y$ 分子により $\mathrm{Si}-$ $\mathrm{H}$ 結合が切断され, その結果, 界面には $D_{\mathrm{it}}$ が生成し, 反応 生成物 $X$ は膜中を漂い, さらなる反応をひき起こすことに なる. 前述の Kushida-Abdelghafar ら 7)により議論されたシ リコン酸窒化膜の NBTI の原因と考えられる (1) 式および (2)式の反応はこのタイプの機構である.

\section{3. 理論的アプローチ}

\section{1 窒化膜形成メカニズムの解明}

原子と電子の相互作用については, 既に多くの理論計算が なされており, 現在では第一原理計算や非経験的分子軌道計 算がさまざまな分野で使われるようになってきてい る7,23,30,34,35). 第一原理計算は, 実験結果をパラメータとし て用いることなく, Schrödinger 方程式を解くことにより求 められる原子の電子状態を基本にして, 分子系や凝縮系の計 算を行うものである.このため, 実験データに左右されるこ となく, 物性值の予測や計算機シミュレーションを行うこと ができる。

ここでは, 第一原理計算による $\mathrm{Si}(100)$ 面の初期窒化過程

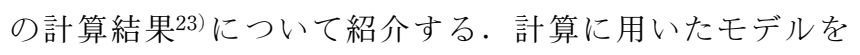
Fig. 1 に示す. 表面を終端していない Si 100$)$ 面と水素終端 した $\mathrm{Si}(100)$ 表面に対して, $\mathrm{N}$ 原子の吸着過程についてのポ テンシャルエネルギー曲線の計算を行った. $\mathrm{N}$ 原子の吸着 点として, $\mathrm{Si}(100)$ 表面の $\mathrm{Si}$ 原子直上 $(\mathrm{A})$, 表面から四層 目の $\mathrm{Si}$ 原子直上 $(\mathrm{B}), \mathrm{Si}$ 原子の存在しない空孔 $(\mathrm{C})$, 二層 目の $\mathrm{Si}$ 原子直上（D）の 4 点を選び, 各吸着点について $\mathrm{N}$ 原子のポテンシャルポテンシャルエネルギー計算を行った.

Fig. 2 は $\mathrm{Si}$ (100) 表面に対する $\mathrm{N}$ 原子吸着についての計算 結果である. ここで, 各吸着点について水素終端の有無につ いて比較を行うと, $\mathrm{B}$ 点（ $\mathrm{N}$ 原子が表面の $\mathrm{H}$ 原子間を通る 


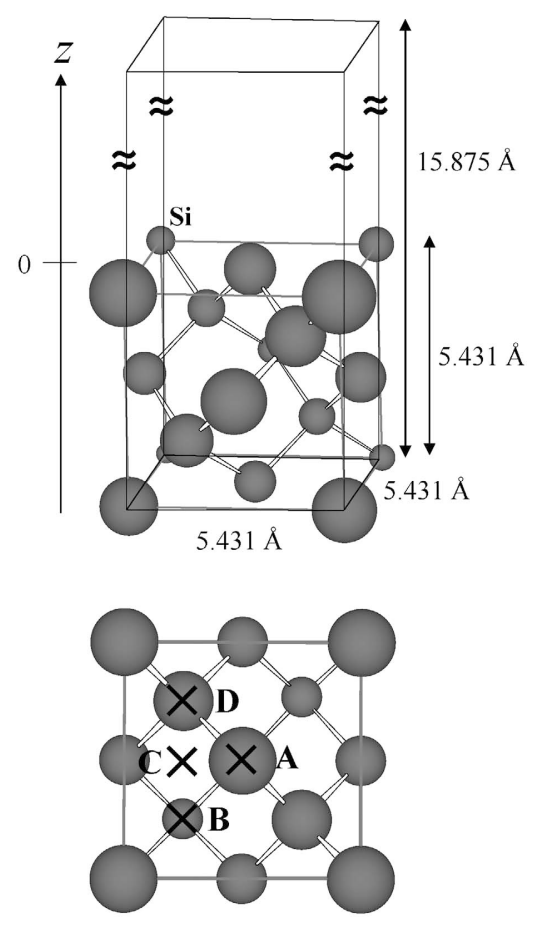

(a)
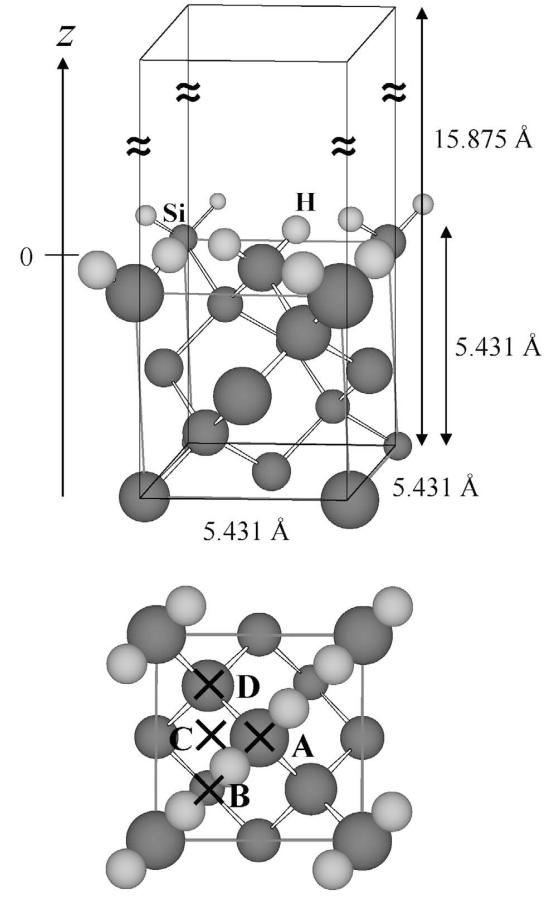

(b)

Fig. 1. Surface models and their top view: (a) bare silicon surface and (b) H-terminated silicon surface.

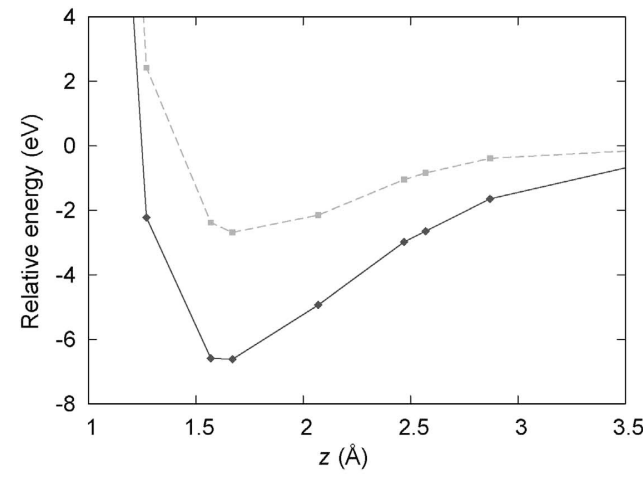

(a)

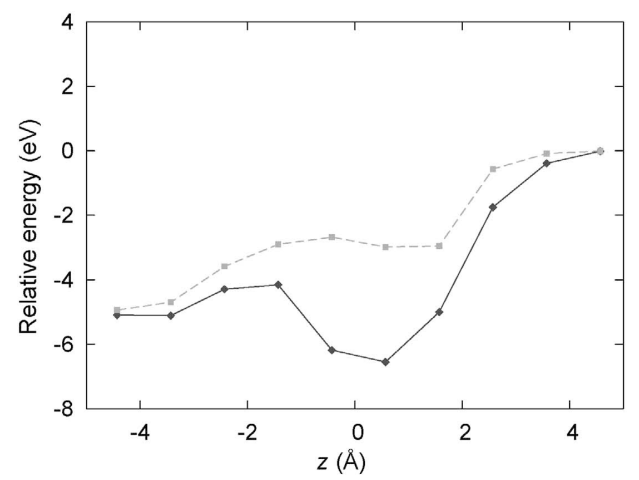

(c)

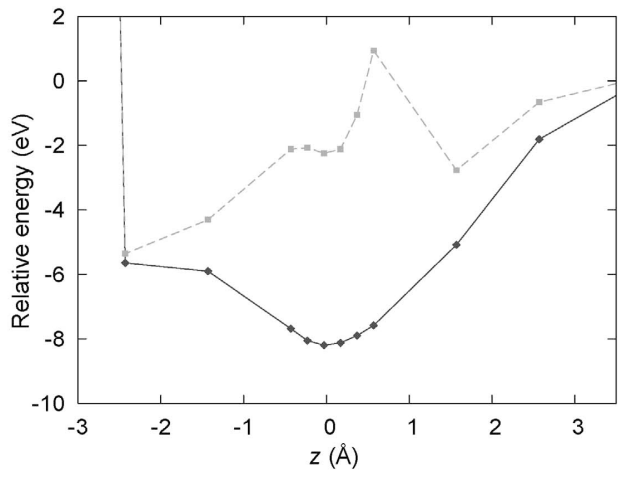

(b)

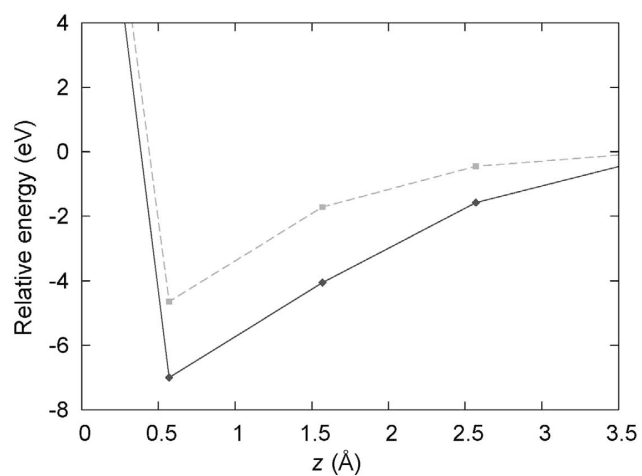

(d)

Fig. 2. Potential energy curves of $\mathrm{N}$ adsorption on (a) site A, (b) site B, (c) site C, and (d) site D. Solid line and dashed line denote the potential energy curves on the bare silicon surface and the $\mathrm{H}$-terminated silicon surface, respectively.

経路）と C 点（ $\mathrm{Si}$ 原子の存在しない空孔）については終端 している $\mathrm{H}$ 原子によるポテンシャル障壁の影響がみられる. $\mathrm{B}$ 点について, むき出しの表面に対しては, $\mathrm{N}$ 原子は一層目
の $\mathrm{Si}$ 原子と結合を作るために一層目で安定に存在すること になるが，表面が水素終端されている場合は，一層目の $\mathrm{Si}$ 原子に達することができない。一方, $\mathrm{C}$ 点については, $\mathrm{N}$ 原 
子はむき出しの表面上で $\mathrm{Si}-\mathrm{N}$ 結合を作るために $\mathrm{Si}$ 層に潜 ることはないが, 表面が水素終端されている場合は, $\mathrm{N}$ 原 子の表面における安定化がそれほど大きくないために，N 原子が $\mathrm{Si}$ 層に潜り込むことが考えられる。 また， A 点と D 点については, 表面終端の有無にかかわらず, $\mathrm{N}$ 原子は表 面上で $\mathrm{Si}-\mathrm{N}$ 結合を生成すると考えられる．この結果から， 吸着点によっては $\mathrm{H}$ 原子の有無にかかわらず安定な $\mathrm{Si}-\mathrm{N}$ 結 合が生成されることから, 水素終端表面に多量の $\mathrm{N}$ 原子が 供給された場合には, 表面の $\mathrm{Si}-\mathrm{H}$ 結合が $\mathrm{Si}-\mathrm{N}$ 結合に置換 することにより解離した水素が $\mathrm{H}, \mathrm{H}^{+}, \mathrm{H}_{2}$ の状態で表面を 漂うことが予想される.

また， A 点と D 点について， $\mathrm{N}_{2} \mathrm{O}$ ガスによる $\mathrm{Si}(100)$ 表 面の窒化過程の計算を行った結果, $\mathrm{Si}(100)$ 表面に対する水 素終端の影響はあるものの, 以下のような反応過程が得られ た。

$$
\begin{aligned}
& \mathrm{Si}(100)+\mathrm{N}_{2} \mathrm{O} \longrightarrow \mathrm{N}(\mathrm{ad}) \cdot \mathrm{Si}(100)+\mathrm{NO} \\
& \mathrm{H}-\mathrm{Si}(100)+\mathrm{N}_{2} \mathrm{O} \rightarrow \mathrm{N}(\mathrm{ad}) \cdot \mathrm{H}-\mathrm{Si}(100)+\mathrm{NO}
\end{aligned}
$$

つまり, $\mathrm{Si}(100)$ 表面の状態にかかわらず， $\mathrm{N}_{2} \mathrm{O}$ 分子は $\mathrm{Si}-\mathrm{N}$ 結合を生成するとともに NO 分子が解離することを示して いる.

\section{2 酸窒化膜の膜構造}

酸窒化膜の構造と電子状態についても第一原理計算を用い た議論がなされている7,30,34-36). Scopel ら ${ }^{37)}$ は経験的パラ メータを用いた原子間ポテンシャルによりモンテカルロ $(\mathrm{MC})$ シミュレーションを行い, $\mathrm{N}_{2} \mathrm{O}$ および $\mathrm{SiH}_{4}$ 雾囲気で 形成される $\mathrm{SiON}$ のアモルファス構造（a-SiON）のモデル 化を行っている. 計算より得られる a-SiON の構造と X 線解 析の結果との一致が確かめられている。 また, a-SiON 中の $\mathrm{Si}$ 原子に結合している原子は, $\mathrm{O}_{3} \equiv \mathrm{Si}-\mathrm{N}$ の配位が目立つが, $\mathrm{N}$ 原子の密度の増加に伴って $\mathrm{O}_{2}=\mathrm{Si}=\mathrm{N}_{2}$ の構造も増加する といえる.

一方, Rignanese $5^{34)}$ とUshio $5^{35)}$ は第一原理計算に基 づき, $\mathrm{Si} / \mathrm{SiO}_{2}$ 界面および $\mathrm{Si} / \mathrm{SiON}$ 界面における反応過程と 電子構造についての N $(1 s)$ シフトを調べることによって界 面構造の計算結果と実験結果の比較を行っている. Ushio ら ${ }^{35)}$ により, $\mathrm{Si} / \mathrm{SiO}_{2}$ 界面と $\mathrm{Si} / \mathrm{SiON}$ 界面に対するホール注 入と $\mathrm{H}_{2} \mathrm{O}$ 分子の反応過程が扱われている. そこでは, 界面 近傍に $\mathrm{H}_{2} \mathrm{O}$ 分子が存在する場合にホールが注入されると, $\mathrm{H}_{2} \mathrm{O}$ から $\mathrm{H}_{2}$ が解離し, $\mathrm{O}$ 原子は界面において $\mathrm{Si}-\mathrm{O}$ 結合を 作る.このとき, 界面の $\mathrm{Si}$ 原子上にダングリングボンド $\left(D_{\mathrm{it}}\right)$ が残り，さらに酸化膜中の $\mathrm{O}$ または $\mathrm{N}$ 原子上に $Q_{\mathrm{f}}$ が 生じる. NBTI のモデルとして, 界面の $\mathrm{Si}-\mathrm{H}$ 結合がホット ホールによって切断され, 解離した $\mathrm{H} や \mathrm{H}^{+}$が酸化膜中を 移動することにより，膜中に $Q_{\mathrm{f}}$ が生じるということであっ たが, Ushio らの計算では $\mathrm{H}_{2} \mathrm{O}$ とホットホールの存在のた めに界面の $D_{\mathrm{it}}$ と酸化膜中の $Q_{\mathrm{f}}$ がもたらされることが示さ れている.さらに，このような反応は $\mathrm{Si} / \mathrm{SiO}_{2}$ 界面よりも $\mathrm{Si} / \mathrm{SiON}$ 界面に抢いて起こりやすいという結果が得られて いる.

\section{3 誘電物性に関する第一原理計算}

$\mathrm{SiO}_{2}$ 膜の誘電率は3.98) として知られるが, 酸化膜の薄膜 化により信頼性を維持することが困難となっている。そこ
で, 膜厚はリーク電流を抑制できる膜厚でかつ高誘電率の酸 化膜を用いることにより換算膜厚を下げることが考えられ る.しかし，一般的には高誘電率を示す酸化物はバンドギャ ップが小さいことが知られており, ゲート電極と基板側のバ ンドオフセットに適したバンドギャップを持つ高誘電率酸化 膜が望まれている.

第一原理計算による誘電率の計算は, Gonze ら 27 によっ て導出されているところによると,

$$
\varepsilon_{\alpha \beta}(\omega)=\varepsilon_{\alpha \beta}^{\infty}+\frac{4 \pi}{\Omega_{0}} \sum_{m} \frac{S_{\mathrm{m}, \alpha \beta}}{\omega_{\mathrm{m}}^{2}-\omega^{2}}
$$

となり，ここでは $S_{\mathrm{m}, \alpha \beta}$ 振動子強度である. 第一原理計算に より $S_{\mathrm{m}, \alpha \beta}$ を求めることにより，(11)式からイオン分極を考 慮した誘電率テンソルが計算される. Rignanese ら ${ }^{28,29)}$ はこ の計算方法によりいくつかの酸化物やシリケート化合物につ いて計算を行っている. 特に, $\mathrm{ZrSiO}_{4}$ と $\mathrm{HfSiO}_{4}$ の計算結 果 ${ }^{28,29)}$ については, 実験と良い一致が得られている。ただ し，(11)式の誘電率は, 系全体としての挙動を加味した空 間的に平均化された誘電率であり, 実験值との対応が取りや すい反面, 結晶性の良くない系についてはモデルの規模によ って值にばらつきが出ることが考えられる.

一方, Tachibanaによって提案された局所誘電率38)の概念 によると, 外部電場 $(\vec{D}(\vec{r}))$ と内部電場 $(\vec{E}(\vec{r}))$ は誘電率 テンソル $(\vec{\varepsilon}(\vec{r}))$ によって以下のように関係付けられるこ とから，

$$
\begin{aligned}
& \vec{D}(\vec{r})=\left(1+\vec{\chi}_{\mathrm{e}}\right) \vec{E}(\vec{r})=\vec{\varepsilon}(\vec{r}) \vec{E}(\vec{r}) \\
& \vec{E}(\vec{r})=\vec{D}(\vec{r})-4 \pi \vec{P}(\vec{r})
\end{aligned}
$$

系の分極 $\vec{P}(\vec{r})$ を知れば $\vec{\varepsilon}(\vec{r})$ を求めることができる。 また, $\hat{\bar{D}}(\vec{r})$ と $\hat{\vec{P}}(\vec{r})$ は演算子として次のように定義される.

$$
\begin{aligned}
& \hat{D}(\vec{r})=-\operatorname{grad} \hat{A}_{0 \mathrm{M}}(\vec{r})-\frac{1}{c} \frac{\partial}{\partial t} \hat{\hat{A}}_{\mathrm{M}}(\vec{r}) \\
& \hat{\hat{P}}(\vec{r})=\frac{1}{4 \pi} \operatorname{grad} \hat{A}_{0 \mathrm{~A}}(\vec{r})+\frac{1}{4 \pi c} \frac{\partial}{\partial t} \hat{A}_{\mathrm{A}}(\vec{r})
\end{aligned}
$$

ここで, A と M はそれぞれ, 注目している系とその外部系 を意味する。この計算の特徵は, (12)式から(15)式の一連 の計算において，それぞれの物理量が各点で定義されている ことであり, 結果として空間の任意の点に抢ける $\vec{\varepsilon}(\vec{r})$ を知 ることができる． $\vec{\varepsilon}(\vec{r})$ を見ることができることから，系の 構造と電子状態, さらにはその電場応答を関係付けて議論す ることができる. Fig. 3 に $\mathrm{Si}(\mathrm{OH})_{4}$ について計算した局所 誘電率 $\vec{\varepsilon}(\vec{r})$ の固有值と固有べクトルの図を示す. 各点にお ける電子の電場応答による誘電率が可視化され, 特に各原子 周りの電子による誘電率が明らかとなる.

\section{4. ま め}

本稿では, シリコン酸窒化膜の形成過程ならびに Si / $\mathrm{SiON}$ 界面と $\mathrm{SiON}$ 膜中の電子状態に注目し, 実験結果とそ れらを理解するための理論計算について概要を述べた. Si/ $\mathrm{SiO}_{2}$ 界面の窒化と NBTI の関係について, 実験結果に対し て従来から考えられてきた理論モデルと第一原理計算による 反応過程の解析について紹介した. 第一原理計算によると, ホットホールの注入による $\mathrm{Si}-\mathrm{H}$ 結合の切断による $\mathrm{H}$ また は $\mathrm{H}^{+}$の解離とそれらの酸化膜内への侵入による固定電荷の 


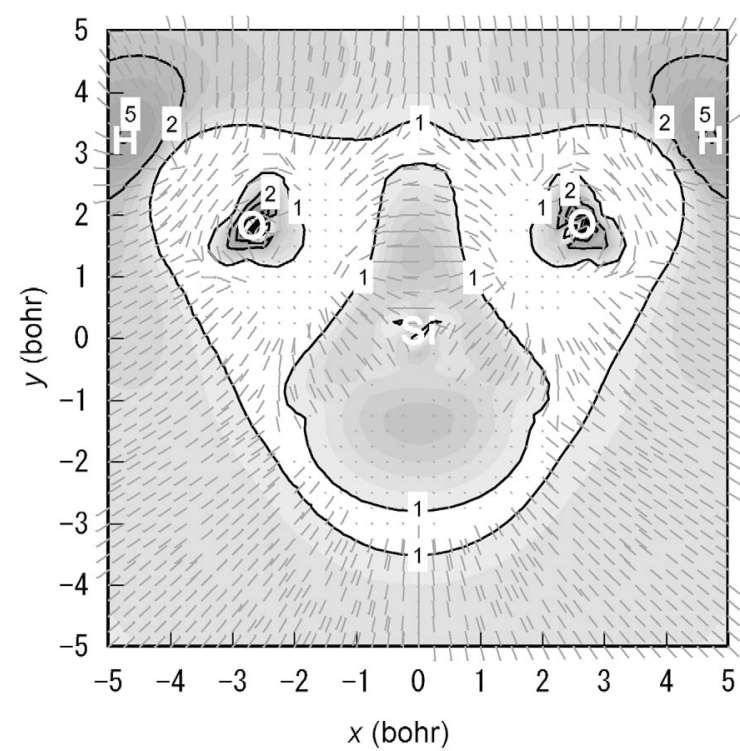

Fig. 3. Contour map of the local dielectric constant. Contour lines show the boundaries of 1.0, 2.0, and 5.0. Gray scale represents the regions of $\varepsilon(\vec{r})$ greater than 1.0.

増加が示された.さらには, ホットホールと $\mathrm{H}_{2} \mathrm{O}$ の存在に よる界面準位の生成と膜中の固定電荷の生成機構についても 明らかとなった。

また, 誘電率の計算方法について既にさまざまな方法が発 表されていることから，ゲート絶縁膜の誘電物性についても 実験と理論計算の両面から研究を進めることができる状況に あり,ここではその一部について紹介した.

\section{〔文献〕}

1) H. Hwang, W. Ting, B. Maiti, D.-L. Kwong and J. Lee: Appl. Phys. Lett., 57 (1990) 1010.

2) S. V. Hattangady, H. Niimi and G. Lucovsky: Appl. Phys. Lett., 66 (1995) 3495 (1995).

3) L. G. Gosset, J. J. Ganem, H. J. von Bardeleben, S. Rigo, I. Trimaille, J. L. Cantin, T. Åkermark and I. C. Vickridge: J. Appl. Phys., 85 (1999) 3661.

4) J. P. Chang, M. L. Green, V. M. Donnelly, R. L. Opila, J. Eng, Jr., J. Sapjeta, P. J. Silverman, B. Weir, H. C. Lu, T. Gustafsson and E. Garfunkel: J. Appl. Phys., 87 (2000) 4449.

5) J. P. Xu, P. T. Lai and Y. C. Cheng: Appl. Phys. A, 70 (2000) 101.

6) M. L. Green, E. P. Gusev, R. Degrave and E. L. Garfankel: J. Appl. Phys., 90 (2001) 2057.

7) K. Kushida-Abdelghafar, K. Watanabe, J. Ushio and E. Murakami: Appl. Phys. Lett., 81 (2002) 4362.

8) K. Muraoka, K. Kurihara, N. Yasuda and H. Satake: J. Appl. Phys., 94 (2003) 2038.

9) D. K. Schroder and J. A. Babcock: J. Appl. Phys., 94 (2003) 1.
10) M. Yoshimoto, T. Maeda, T.Ohnishi, G. H. Lee and H. Louinuma: Mater. Res. Soc. Symp. Proc., 41 (1996) 210.

11) G. D. Wilk and R. M. Wallace: Appl. Phys. Lett., 74 (1999) 2854.

12) G. D. Wilk and R. M. Wallace: Appl. Phys. Lett., 76 (2000) 112.

13) E. P. Gusev, M. Copel, E. Cartier, I. J. R. Baumvol, C. Krug and M. A. Gribelyuk: Appl. Phys. Lett., 76 (2000) 176.

14) G. D. Wilk, R. M. Wallace and J. M. Anthony: J. Appl. Phys., 87 (2000) 484.

15) J. P. Liu, P. Zaumseil, E. Bugiel and H. J. Osten: Appl. Phys. Lett., 79 (2001) 671.

16) G. D. Wilk, R. M. Wallace and L. M. Anthony: J. Appl. Phys., 89 (2001) 5243.

17) Y. Kim, S. Ohmi, K. Tsutsui and H. Iwai: Proc. 34th European Solid-State Device Research Conference (ESS-DERC2004, Leuven, 2004) p. 81.

18) K. O. Jeppson and C. M. Svensson: J. Appl. Phys., 48 (1977) 2004.

19) D. K. Schroder and J. A. Babcock: J. Appl. Phys., 94 (2003) 1.

20) S. Fujieda, Y. Miura, M. Saitoh, Y. Teraoka and A. Yoshigoe: Microelectron. Rel., 45 (2005) 57.

21) H. Y. Yang, H. Niimi and G. Lucovsky: J. Appl. Phys., 83 (1998) 2327.

22) G. Lucovsky, Y. Wu, H. Niimi, H. Yang, J. Keister and J. E. Rowe: J. Vac. Sci. Technol. A, 18 (2000) 1163.

23) S. Yoshida, K. Doi, K. Nakamura and A. Tachibana: Appl. Surf. Sci., 216 (2003) 141.

24) K. Doi, K. Fujitani, N. Kadowaki, K. Nakamura, A. Tachibana and T. Hattori: Jpn. J. Appl. Phys., 44 (2005) 6115.

25) K. Doi, K. Nakamura and A. Tachibana: Appl. Surf. Sci., 216 (2003) 463.

26) P. W. Peacock, K. Xiong, K. Tse and J. Robertson: Phys. Rev. B, 73 (2006) 075328.

27) X. Gonze and C. Lee: Phys. Rev. B, 55 (1997) 10355.

28) G.-M. Rignanese, X. Gonze and A. Pasquarello: Phys. Rev. B, 63 (2001) 104305.

29) G.-M. Rignanese, X. Gonze, G. Jun, K. Cho and A. Pasquarello: Phys. Rev B, 69 (2004) 184301.

30) D. Fischer, A. Curioni, S. Billeter and W. Andreoni: Phys. Rev. Lett., 92 (2004) 236405.

31) K. Nakamura, K. Doi, K. Fujitani and A. Tachibana: Phys. Rev. B, 71 (2005) 045332.

32) C.-H. Ang, C.-M. Lek, S.-S. Tan, B.-J. Cho, T. Chen, W. Lin and J.-Z. Zhen: Jpn. J. Appl. Phys., 41 (2002) L314.

33) E. H. Nicollian and J. R. Brews: MOS Physics and Technology (John Wiley and Sons, Hoboken 2003) p. 794.

34) G.-M. Rignanese, A. Pasquarello, J.-C. Charlier, X. Gonze and R. Car: Phys. Rev. Lett., 79 (1997) 5174.

35) J. Ushio, T. Maruizumi and K. Kushida-Abdelgafar: Appl. Phys. Lett., 81 (2002) 1818.

36) C. McGuinness, D. Fu, J. E. Downes, K. E. Smith, G. Hughes and J. Roche: J. Appl. Phys., 94 (2003) 3919.

37) W. L. Scopel, A. J. R. da Silva, W. Orellana, R. J. Prado, M. C. A. Fantini, A. Fazzio and I. Pereyra: Phys. Rev. B, 68 (2003) 155332 .

38) A. Tachibana: J. Mol. Model., 11 (2005) 301. 